\title{
ANALISIS KEMAMPUAN GURU KELAS MELAKSANAKAN PENILAIAN DALAM PROSES PEMBELAJARAN
}

\author{
Abdurrahman ${ }^{1}$ \\ ${ }^{1}$ Universitas Pendidikan Mandalika Mataram (UNDIKMA) \\ Jl. Pemuda 59 A Mataram 83126 \\ email: abdurrahman@ikipmataram.ac.id
}

\begin{abstract}
Abstrak: Penilaian yang dilaksanakan oleh guru masih didominasi oleh penilaian yang digunakan mengukur aspek kognitif yang bisa diterapkan dalam penilaian kurikulum. Atas dasar tersebut penelitian ini bermaksud untuk menemukan proses penilaian yang dilaksanakan oleh guru di MI Nurul Islam Karangpule Kecamatan Sekarbela Kota Mataram. Adapun focus penelitian ini adalah (1) bagaimanakah guru kelas mengembangkan instumen penilaian proses pembelajaran sesuai dengan sistem penilaian di MI Nurul Islam Sekarbela Kota Mataram tahun 2021 (2) Bagaimanakah guru kelas melaksanakan penilaian berdasarkan proses pembelajaran instrumen penilaian yang telah dikembangkan? Pendekatan dalam penelitian ini adalah kualitatif, dengan tiga tahap pengumpulan data yaitu, (1) pralapangan, (2) kegiatan lapangan dan (3) analisis intensif. Metode pengumpulan data menggunakan metode pengamatan (observasi), wawancara dan dokuemntasi. Seluruh data dianalisis dengan menggunakan (1) reduksi data, (2) penyajian data dan (3) verifikasi data. Adapun hasil yang diperoleh adalah (1)Guru MI Nurul Islam Sekarbela Kota Mataram sudah mampu membuat istrumen penilaian peruses pembelajran sesuai dengan sistem penilaian (2) Guru MI Nurul Islam Sekarbela Kota Mataram hanya sebagian yang melaksanakan penilaian berdasarkan instrumen penilaian yang dikembangkan pada Rencana Pelaksanan Pembelajaran (RPP).
\end{abstract}

Kata Kunci: Pengembangan, Pelaksanaan Penilaian, Proses pembelajaran.

\section{PENDAHULUAN}

Kegiatan pembelajaran merukapan suatu sistim terdiri dari berberapa kompenen yaitu: guru, siswa, tujuan, bahan materi, sarana-prasarana, strategi dan metode serta penilaian. Keseluruhan komponen tersebut tidak dapat berdiri sendiri, komponen satu dengan komponen lainnya saling berhubungan. Guru harus mencapai tujuan, maupun efektifitas proses pembelajaran melalui penilaian. Dengan penilaian guru akan dapat mengukur penguasaan kompetensi siswa, juga dapat dijadikan sebagai umpan balik bagi guru untuk memperbaiki proses pembelajaran agar semakin efektif. Selain itu guru juga dapat menggunakan hasil penilaian sebagai bahan pertimbangan untuk mengambil keputusan tentang siswa, sehingga dapat dijadikan sebagai bahan laporan kepada orang tua siswa.

Penilaian yang dilakukan terbatas pada aspek tertentu saja, tidak dapat dijadikan sebagai satu-satunya dasar pengambilan keputusan terhadap perkembangan siswa. Oleh karena itu guru harus melakukam penilaian untuk mengukur aspek perkembangan siswa yang berbeda . Penilaian sebagai komponen tidak terpisahkan dalam pembelajaran harus direncanakan guru sejak awal sebelum kegiatan pembelajaran dilaksanakan.

Umumnya masih ditemukan bahwa guru mengembangkan instrument penilaian sesaat sebelum penilaian akan dilaksanakan. Guru seharusnya telah mempersiapkan seluruh rencana kegiatan pembelajaran termasuk mengembangkan instrument penilaian sebelum kegiatan pembelajaran dilaksanakan. Selain itu instrument penilaian yang dikembangkan dan dilaksanakan guru masih didasarkan pada sistem penilaian. Sedangkan kurikulum yang di pakai adalah kurikulum Prototipe. Penelitian ini dimaksudkan untuk menemukan penilaian proses pembelajaran yang dilaksanakan oleh guru di MI Nurul Islam Sekarbela Kota Mataram. 


\section{KAJIAN TEORI}

1. Pengertian Penilaian

Penilaian adalah upaya sistematik dan sistemik yang dilakukan melalui pengungumpulan data atau informasi yang valid dan reabel,selanjutnya data atau informasi tersebut diolah sebagai upaya melakukan pertimbangan untuk pengambilan suatu kebijakan pendidikan. Dalam Permendikbud Nomor 66 tahun 2013 dijelaskan bahwa Penilaian pendidikan sebagai proses pengumpulan dan pengolahan informasi untuk mengukur pencapaian hasil belajar peserta didik mencakup: penilaian otentik, penilaian diri, penilaian berbasis portofolio, ulangan, ulangan harian, ulangan tengah semester, ulangan akhir semester, ujian tingkat kompetensi, ujian mutu tingkat kompetensi, ujian nasional, dan ujian sekolah/madrasah.

2. Penilaian dalam Kurikulum

a. Konsep dan prinsip penilaian dalam kurikulum

Kurikulum terkini juga merupakan kurikulum berbasis kompetensi dan mengunakan istilah KTSP untuk kurikulum yang dikembangkan oleh sekolah atau satuan pendidikan. Beberapa konsep yang digunakan dalam kurikulum 2013 perlu dipahami terlebih dahulu dalam upaya memahami konsep penilaian yang harus dilakukan ,yakni konsep kompetensi dan standar kompetensi.Kompetensi adalah kemampuan bersikap, berpikir, dan bertindak secara konsisten sebagai perwujudan dari pengetahuan sikap, pengetahuan dan keterampilan yang dimiliki oleh peserta didik. Sebuah standar perlu ditetapkan sebagai patokan atau acuan pencapaian kompetensi yang akan digunakan dalam penilaian.penetapan standar kompetensi dalam bentuk Standar Kompetensi Lulusan (SKL), Kompetensi Inti (KI) dan Kompetensi Dasar (KD) perlu dilakukan sebagai acuan dalam proses pendidikan.

Pada kurikulum, aspek yang dinilai tergantung pada Standar Kompetensi Lulusan (SKL), Kompetesi Inti (KI), Kompetisi Dasar (KD). SKL mencakup aspek sikap (attitude), pengetahuan (knowledge), dan keterampilan (skills. Kompetensi Inti mencakup aspek kompetensi sebagai berkut.1) KI-1: aspek sikap peserta didik terhadap Tuhan, 2) KI-2: aspek sikap peserta didik terhadap diri sendiri dan terhadap lingkungan,3 ) KI-3: aspek pengetahuan peserta didik dan 4) KI-4: aspek keterampilan peserta didik.

Setiap KI mencakup beberapa rumusan KD yang bebeda untuk lingkup materi pokok tertentu. Jadi, untuk suatu materi pokok tertentu aka nada empat KD sebagai berikut: 1) KD pada KI-1: aspek sikap peserta didik terhadap Tuhan, 2) KD pada KI-2: aspek sikap peserta didik terhadap diri sendiri dan terhadap lingkungan, 3) KD pada KI3: aspek pengetahuan peserta didik,4) KD pada KI-4: aspek keterampilan peserta didik.

Penilaian hasil belajar peserta didik dalam kurikulum 2013 pada jenjang pendidikan dasar dan menengah didasarkan pada prinsip-prinsip yang hampir sama denagan KTSP 2016. Prinsip-prinsip yang ditetapkan dalam Peraturan Menteri Pendidikan tentang penilaian hasil belajar yang dijabarak secara lebih rinci sebagai berikut:1) Sahih, yaitu penilaian dilakukan mengunakan instrument yang sesuai untuk mengukur kompetensi dan didasarkan pada data yang mencerminkan kemampuan yang diukur, 2) Objektif,yauitu penilaian didasarkan pada prosedur atau criteria yang jelas sehingga tidak dipengaruhi oleh subjektifitas penilai.3) Adil, yakni penilaian tidak menguntukan atau merugi peserta didik yang berkebutuhan khusus dan memiliki perbedaan dalam latar belakang agama, suku, budaya, adat istiadat, status social ekonomi dan/atau gender, 3) Terpadu,yakni dilakukan secara terintegrasi atau merukan 
salah satu komponen yang tak terpisahkan dari kegitan pembelajaran,4) Menyeluruh dan berkesinambungan, yakni mencakup semua aspek kompetensi dengan mengunakan mengunakan teknik penilaian yang sesuai, dan dapat digunakan untuk menentukan perkembangan kemampuan peserta didik,3) Ekonomis, berarti penilaian yang efektif dan efisien dalam perencanaan, pelaksaan dan pelaporan.4) Transparan, berate prosedur penilaian, criteria penilaian, dan dasr pengambilan keputusan dapat diakses oleh semua pihak, 5) Terbuka, yakni memiliki kejelasan dalam prosedur penilaian dan criteria penilaian, 6) Akuntabel, yakni ditinjau dari pelaksanana dan hasilnya ,penilaian dapat dipertanggungjawabkan baik dari segi teknik, prosedur, maupun hasilnya, 7) Edukatif ,berarti mendidik dan memotivasi peserta didik dan guru. Edukatif juga berarti penilaian dilakukan untuk kepentingan dan kemajuan pendidikan peserta didik, 8) Beracuan kriteria,yakni pelaksannan penilaian didasarkan pada ukuran atau criteria pencapaian kompetensi yang ditetapkan, 9) Sistematis,yakni pelaksanaan penialaian dilakukan secara terencana dan bertahapdenagn mengikuti langkah-langkah baku.

b. Karakteristik Penelitian dalam Kurikulum 2013

Penilaian dalam kurikulum memiliki karakteristik penilaian yang berbeda dengan kurikulum sebelumnya. Adapun pembahasannya sebagai berikut:

1) Karakterristik penilaian .Penilaian hasil belajar dalam kurikulum memiliki beberapa karakteristik, yakni: a) Belajar tuntas (mastery learning).peserta didik harus memenuhi kriteria ketuntasan indikator nilai yang telag ditetapkan denag prosedur yang benar dan hasil yang baik, b) Penilaian autentik.Penilaian autentik sangat penting untuk diterapkan dalam implementasi kurikulum karena penilaian autentik menuntut peserta didik mendemostrasikan pengetahuan dan keterampilan untuk menyelesaikan masalah nyata. Penilaian autentik mengunakan berbagai cara dan kriteri holistik, yakni kompetensi secara utuh yang mereflesikan pengetahuan,keterampilan dan sikap, c) Berkesinambungan.Penelian harus dilakukan secara berkesinambungan dengan tujuan untuk mendapatkangambaran yang utuh mengenai perkembangan hasil belajar peserta didik, memantau proses, kemajuan, dan perbaikan hasil terus-menerus dalam bentuk penilaian proses, dan berbagai jenis ulangan secara berkelanjutan, d) Berdasarkan acuan patokan atau kriteria.Penilaian dalam implementasi Kurikulum pada jenjang pendidikan dasar, proporsi pembinaan karakter lebih diutamakan dari pada proporsi pembinaan akademik, e) Mengunakan teknik penilaian bervariasi.

2) Karakteristik Penilaian Disekolah Dasar (SD)Karakteristik penilaian pada setiap jenjang pendidikan berbeda-beda.Karakteristik penilaian disekolah Dasar (SD) sebagai berikut: a) Standar Kompetebsi Lulusan SD untuk domain sikap memiliki perilaku yang mencerminkan sikap, beriman, berakhlak mulia, percaya diri, dan bertanggung jawab dalam berinteraksi secara efektif dengan lingkungan sosial dan alam disekitar rumah, sekolah, dan tempat bermain, b) Standar Kompetebsi Lulusan SD untuk domain pengetahuan memiliki pengetahuan fakultas dan konseptual ilmu pengetahuan, tegnologi, seni, budaya, humanioral, dengan wawasan kebangsaan, kewarganegaraan, dan peradaban terkait fenomena dan kejadian di lingkungan rumah, sekolah, dan tempat bermain, c) Standar Kompetesi Lulusa SD untuk domain keterampilan memiliki kemampuan piker dan tindak yang efektif dan kreatif dalam rana absrak dan konkret, d) Mengunakan pendekatan pembelajaran tematik interatif, e) Berbagai kompetesi dasar dirajuk dengan tema, f) Penilaia dilakukan secara utuh dan menyeluruh terhadap semua aspek penilaian, g) Kegiatan penilaian harus sudah direncanakan bersamaan denag kegiatan penyusunan program semester 
dan dilaksanakan sesuai dengan program yang telah disusun, h) Penilaian dilakukan dengan mengacu pada indicator-indikator dari masing-masing kompetensi dasar.

c. Metode Penilaian Kurikulum

Penilaian dapat dilakukan selama pembelajaran berlangsung (penilaian proses) dan setelah proses pembelajaran selesai dilaksanakan (penilaian produk).

Metode penilaian yang harus digunakan disekolah untuk implementasi kurikulum 2013 telah ditetapkan dalam Pemendikbud Nomor 66 Tahun 2013 tentang standar penilaian pendidikan.Pada tahun 2015 dikeluarkan permendikbud Nomor 53 Tahun 2015 tentang Penilaian hasil belajar oleh pendidik pada Pendidikan Dasar dan Menegah, peraturan mentri pendidikan adalah senagai berikut:

1) Penilain kompetensi sikap ,Untuk mengukur kompetensi sikap digunakan metode nontes. Metode nontes pada umumnya menggunakan intrumen sebagai berikut: a) Observasi, merukan teknik penilaian yang dilakuanan secara berkesinambungan dengan mengunakan indra, baik secara langsung maupun tidak langsung denagn pedoman observasi yang berisi sejumlah indicator perikaku yang diamati. Observasi adalah teknik penilaian yang dilakukan denagn mencatat hasil pengamatan terhadap objek tertentu denag terlebih dahulu membuat instrumen sesuai denagn objek, b) penilaian diri sendiri,Peserta didik diminta untuk mengemukakan secara jujur kelebihan dan kekurangan dirinya dalam kontek pencapaian kompetensi, c) Penilaian atar peserta didik, merupakan teknik penilaian dengan memminta peserta didik untuk saling menilai terkait denagn pencapaian kompetensi, d)Jurnal, merupakan cacatan pendidik didalam dan diluar kelas yang berisi informasi hasil pengamatan tentang kekuatan dan kelemahan peserta didik yang berkaitan dengan sikap dan perilaku.

2) Penilain Kompetensi Pengetahuan. Berdasrkan Permendikbut Nomor 53 Tahun 2015, pendidik dapat menenilai kompetensi pengetahui melalui, a) tes tulis, b) tes lisan, dan c) penugasan.

3) Penilaian Kompetensi Keterampilan, Pendidik menilai kompetensi keterampilan melalui penilaian kinerja,yaitu penilaian yang menuntut peserta didik mendemostrasikan suatu kompetensi tertentu. Berikut ini dijabarkan beberapa teknik yang umum digunakan untuk menilai keterampilan peserta didik: a) Unjuk kerja dan tes praktik penilaian yang menuntut respons berupa keterampilan melakukan suatu aktivitas atau perilaku sesuai dengan tuntutan kompetensi.b) Proyek adalah tugastugas belajar yang meliputi kegiatan perancangan, pelaksanaan dan pelaporan secara tertulis maupun lisan dalam waktu tertentu.c) Penilaian portopolio adalah penilaian yang dilakukan dengan cara menilai kumpulan seluruh karya peserta didik dalam bidang tertentu yang bersifat-reflektif interaktif.

d. Penilaian proses pembelajaran

Penilaian proses pembelajaran dimaksudkan untuk menilai kualitas pembelajaran serta interaksi karakter kompetesi peserta didik,termasuk bagaiman kompetensi peseerta didik termasud bagimana tujuan-tujuan belajar direalisasikan.Dalam hal ini,penilain proses dilakukan untuk menilai aktivitas, kreativitas dan keterlibatan peserta didik dalam pembelajaran,terutama keterlibatan mental, emosiaonal dan sosial dalam pembentukan kompetensi serta karakter peserta didik.

Penilaian proses belajar dapat dilkukan dengan pengamatan (observasi), dan refleksi. Pengamatan dapat dilakukan oleh guru ketika peserta didik sedang mengikuti 
pembelajaran,mengajukan pertanyaan/permasalahan, merespon atau menjawab pertanyaan, berdiskusi dan melakukan kegiatan pembelajaran lainnya,baik didalam kelas maupun diluarkelas.

Di samping melalui pengamatan (observasi), penilaian proses pembelajaran juga dilakukan melalui refleksi. Refleksi bias dilakukan oleh guru bersama peserta didik, dengan melibatkan guru lain (observer) atau pendamping.Refleksi juga melibatkan kepala sekolah ,agar ditinjak lanjuti dengan kebijakan sekolah. Refleksi ini merupakan tinjak lanjut dari observasi, sehingga apa-apa yang dibicarakan dalam refleksi adalah hasil obsevasi, serta hasil-hasil lain yang muncul dalam pembelajaran.

Dalam implementasi kulrikulum 2013, penilaian proses baik yang dilakukan melalui pengamatan maupun refleksi harus ditujukan untuk memperbaiki program pembelajaran dan peningkatan kualitas layanan kepada peserta didik.

\section{METODE PENELITIAN}

1. Rancangan Penelitian

Penelitian ini adalah penelitian deskriptif dengan pendekatan kualitatif. Penelitian ini dimaksudkan mendeskripsikan kondisi obyektif dari variabel yang diteliti tanpa melakukan perlakuan berupa apapun terhadap variabel tersebut. Pendekatan kualitatif digunakan untuk mengetahui dan mempelajari secara mendalam tentang pengembangan instrumen dan pelaksaksanan penilaian sesuia dengan konsep penilaian dalam kurikulum 2013 di MI Nurul Islam Karangpule Sekarbela Kota Mataram Melalui pendekatan ini memungkinkan peneliti untuk memberikan verifikasi yang realistis yang dapat digunakan sebagai bahan evaluasi dan bahan dalam mengambil kebijakan menentukan pengembangan instrumen dan pelaksanaan penilaian yang sesuai dengan konsep penilaian pada kurikulum 2013 di MI Nurul Islam Karangpule Sekarbela Kota Mataram.

2. Data dan Sumber data

Data yang dimaksudkan dalam penelitian ini adalah informasi yang diperoleh melalui metode pengumpulan data baik melalui, wawancara, observasi dan dokumentasi yang ada di lapangan tentang pengembangan instrumen dan pelaksanaan penilaian yang dilakukan oleh guru di MI Nurul Islam Karangpule Sekarbela Kota Mataram.

Sumber data dalam penelitian kualitatif tidak harus representatif dengan jumlah sumber data, tetapi harus representatif dengan informasi yang bersifat holistik. Informasi yang muncul kemudian dijadikan sebagai dasar dari rancangan dan teori yang muncul melalui penelitian ini. Sumber data yang ditetapkan diharapkan dapat memberikan informasi holistik dan kontekstual. Oleh karena itu penentuan sumber data dalam penelitian ini dilakukan atas dasar tujuan tertentu (porpusive sampling).

Sumber data ini dikelompokkan dalam dua bagian yaitu sumber data berupa subyek penelitian dan tempat penelitian. Subyek dalam penelitian ini adalah mereka yang terlibat dalam berbagai peristiwa pengembangan instrumen penilaian dan pelaksanaan penilaian tersebut dalam kegiatan pembelajaran di Madrasah Ibtidaiyah Nurul Islam Sekarbela. Sumber data yang dimaksud adalah guru-guru di Madrasah Ibtidaiyah Nurul Islam Sekarbela. Namun data yang akan digali terbatas pada unsurunsur (1) pengembangan istrumen penilaian dan pelaksanaan penilaian sesuai dengan prinsip penilaian kurikulum 2013, (2) dokumen instrumen penilain berdasarkan konsep kurikulum 2013. 
Sedangkan tempat penelitian ini adalah tempat menjaring data yang mana data digali karena di lokasi tersebut terjadi peristiwa dalam pengembangan instrumen penilaian dan pelaksanaannya di MI Nurul Islam Karangp Sekarbela Kota Mataram. Adapun sumber data dalam penelitian ini adalah :

a. Guru-guru di MI Nurul Islam Sekarbela Kota Mataram.

b. Kepala MI Nurul Islam Sekarbela Kota Mataram.

3. Pengumpulan Data

Pengukumpulan data dalam penelitian ini, adalah dilakukan denga tiga tahap yaitu 1). Pralapangan,2) lapangan dan 3) analisis intensif.

Pengumpulan data dalam penelitian ini mengunakan metode triagulasi atau gabungan dari metode wawancara,observasi dan dokumentasi.

4. Analisis Data

Analisis data dalam penelitian menggunakan analisis data model interaktif. Analisis data terdiri dari beberapa proses yang saling terkait, yaitu reduksi data, penyajian data dan pengambilan kesimpulan/ verifikasi.

Reduksi data (data reduction),pada tahap reduksi data peneliti menyederhadakan, perangkuman dan penyajian seluruh pontesi data yang ditemukan secara tertulis.

Penyajian data (data display) merupakan bagian kedua dari tahap analisis. Penyajian data merupakan konstruk informasi padat terstruktur yang memungkinkan pengambilan kesimpulan dan penerapan aksi. Oleh karena itu peneliti perlu terlebih dahulu mengkaji proses reduksi data sebagai dasar memberikan pemaknaan data.

Pengambilan kesimpulan atau verifikasi data dimana pada bagian ini melibatkan peneliti untuk melakukan interpretasi data, penetapan makna dari data yang disajikan. Menurut Miles dan Huberman, bahwa dalam tahap ini peneliti bisa menggunakan caracara antara lain metode komparasi, merumuskan pola dan tema, pengelompokan (clustering), metode konfirmasi seperti triangulasi, mencari kasus negatif, menindaklanjuti temuan-temuan dan cek-silang dengan responden.

5. Pemeriksaan Keabsahan Data

Dalam penelitian dengan menggunakan pendekatan kualitatif sebagaimana dalam penelitian ini, maka diperlukan melakukan pengecekan keabsahan data yang diperoleh. Keabsahan data dalam penelitian ini harus dapat dipertanggungjawabkan kevalidan datanya. Akan hal ini peneliti melakukan pengecekan keabsahan data melalui kredibiltas data (credibilty).

\section{HASIL PENELITIAN}

1. Gambaran Umum Lokasi Penelitian

Penelitian ini dilaksanankan di MI Nurul islam sekarbela jalan Swasembada No.120 Kekalek Sekarbela Mataram Nusa Tenggara Barat.

Di MI Nurul Islam terdapat 18 orang guru termaksud kelapa madrasah Guru kelas 11 orang dan guru matapelajaran 6 orang. Tiga orang berstatus PNS dan yang lainnya belum berstatus PNS .

2. Pengembangan instrument peneilaian proses Pembelajaran Oleh Guru

Dari hasil wawancara yang kami lakukan kepada beberapa responden seluruh responden menyatakan selalu menyiapkan rencana peelaksanan pembelajaran (RPP) sebelum melaksanakan proses pembelajaran,tidak ada responden yang tidak menyiapkan rencana pelaksanaan pembelajaran.

Instrumen penilaian proses pembelajaaran di kembangkan sendiri oleh guru. seluruh responden menyatakan selalu mencantumkan komponen penilaian dalam rencana 
pelaksanaan (RPP) yang dibuat.Butir instrument yang dibuat mencakup seluruh aspek yaitu, aspek konitif,afektif dan psikomotorik. Butir instrument tersebut tercakup dalam penilaian proses pembelajaran.

3. Pelaksnanan Penilaian Proses Pembelajaran

Dari semua responden sebagian $28 \%$ mengatakan melakukan penilaian proses pembelajaran, $72 \%$ mengatakan kadang-kadang melakukan proses pembelajaran dan $0 \%$ menyatakan tidak pernah melakukan penilaian proses pembelajaran.

Berdasarkan data yang dikumpulkan oleh peneliti semua RPP sudah mencatupkan instrument penelitian untuk semua aspek, akan tetapi dalam pelaksanaannya banyak guru yang tidak melaksanakan penilaian sesuaian dengan instrument yang telah dicantumkan dalam rencana pelaksanaan pembelajaran (RPP).

\section{PEMBAHASAN}

1. Pengembangan instrument penilaian proses pembelajaran di MI Nurul Islam Sekarbela Mataram

Secara keseluruhan guru telah menyiapkan instrument penilaian untuk mengumpulkan berbagai informasi tentang siswa dalam setiap proses pembelajaran, penilaian hasil belajar oleh pendidik sebagai proses pengumpulan informasi atau bukti tentang capaian pembelajaran peserta didik selama dan setelah proses pembelajaran.

Instrument penilaian telah direncanakan dan disiapkan pendidik bersamaan dengan rencana pelaksanaan pembelajaran dibuat.Dilihat dari semua guru mengembangkan intrumen penilaian bersamaan dengan pembuatan rencana pelaksanaan pembelajaran.Hal ini sangat tepat agar guru tidak membuat instrument penilian sesaat sebelum penilian dilaksanakan.Dengan dikembangakannya instrument penelitian jauh sebelum pelaksanaan proses pembelajaran,instrument akan sesuian dengan tujuan yang ingin dicapai.

Dari data hasil wawancara guru mengembangan instrument penilian untuk semua aspek baik pengetahuan sikap dan keterampilan,seharus demikian guru disemua madrasah harus menjalankan tugas dan fungsinya.

Memperhatikan lembar instrument yang tercantum dalam RPP tersebut guru telah menyiapkan beberapa teknik untuk mengumpulkan informasi tentang perkembangan yang dicapai oleh peserta didik.Dalam melaksanakan penilaian seorang guru dapat mengumpulkan berbagai informasi tentang perkebangan peserta didik dengan mengunakan berbagai teknik evaluasi,sehingga perubahan perilaku dan pengembangan siswa dapat diketahui secara komperensif.

Dengan lengkapnya teknik yang disiapkan oleh guru,selain untuk mengetahui perkembangan siswa juga dapat digunakan untuk mengetahui efektifitas proses pembelajaran yang akan dilakukan.

Dalam menyiapkan instrument penilaian, seharusnya setiap guru mengembangkan instrument penilaian pada ranah kognitif baik tulis maupun lisan, dengan berbagai jenis seperti pilihan ganda, uraian singkat, isian. Instrument penilaian yang dikembangkan selain ranah kognitif, juga mengembangkan instrument penilaian sikap. Dalam kurikulum 2013 instrumen penilaian untuk sikap dapat dikembangkan untuk sikap spiritual maupun sikap social. Instrument penilaian untuk sikap ini seharusnya juga tidak hanya berupa lembar pengamatan, tetapi dapat dilengkapi dengan instrument penilaian anekdot. Dalam istilah instrument penilaian, penilaian ini dikenal dengan catatan anekdot, yaitu alat observasi untuk mencatat kejadian-kejadian yang sifatnya luar biasa, sehingga dianggap penting, misalnya catatan anekdot diperlukan untuk 
mengumpulkan data-data yang dianggap penting dari kasus yang sedang diteliti, pencatatan peristiwa tersebut sebaiknya dilakukan ketika kejadian berlangsung, jangan ditunda.

2. Pelaksanaan Penilaian Proses pembelajaran di MI Nurul Islam

Kurikulum 2013 telah di sosialisasikan sejak 2013 sehinga seharusnya pada saat pelaksanaan penelitian ini seharussnya guru sudah mampu mengembangkan dan melaksanan penilaian sesuai dengan prosedur penilaian dalam kurikulum 2013.

Instrument yang dikembangan harus memuat semua aspek untuk mengukur perkembangan pengetahua,sikap dan keterampilan yang diperloleh pada saat proses pembelajaran berlangsung.

Dalam pelaksanaan penilaian proses pembelajaran guru belum bisa melaksananakan proses penilaian sesuia dengan instrument yang telah dicantumkan dalam rencana pelaksanaan pembelajaran (RPP). Berdasarkan hasil observasi dan wawancara hal tersebut terjadi karena beberapa alasan:

a. Guru masih berpatokan pada system penilaian kurikulum lama karena di anggap lebih mudah diterapkan.

b. Guru mengalami kesulitan untuk menganililis dan menggitegrasikan hasil penilaian proses pembelajaran.

c. Keterbatasan waktu untuk melakukan penilaian proses pembelajaran, karena harus melakukan penilaian secara individu.

d. Guru kesulitan membagi focus atara melakukan penilaian proses pembelajaran dan melayani kebutuhan belajar peserta didik.

e. Guru beranggapan penilaian proses pembelajaran tidak dibutuhkan karena pada akhirnya siswa hanya membutuhkan penilaian kognitif untuk melanjutkan kejenjang pendidikan selanjutnya.

\section{KESIMPULAN}

Guru kelas sudah mampu mengembangkan instrument penilaian proses pembelajaran sesuai dengan prosedur penilaian kurikulum 2013. Hal ini dapat dilihat dari semua guru sudah mampu membuat instrument penelitian dan mencantumkannya dalam rencana pelaksanaan pembelajaran (RPP. Guru kelas belum mampu melakukan penilaian proses pembelajaran sesuai dengan instrument yang telah dibuat. Dengan alasan keterbatasan waktu dan kesulitan dalam menganalisi dan mengintegrasikan hasil penilaian.

\section{DAFTAR PUSTAKA}

Prastowo,Andi.2015.Penyusunan Rencana Pelaksanaan Pembelajaran (RPP) Temati

Tepadu Implementasi Kurikulum 2013 Untuk Sd/Mi.Jakarta:Prenada Media Group

Abdul Sani,Ridwan.2016.Penilaain Autentik.Jakarta:Bumi Aksara

Mulyasa,E.2016. Pengembangan dan Implementasi Kurikulum 2013.Bandung:PT

Remaja Rosdakarta.

Sugiyono.2013.petode penelitian kuantitatif,kualitatif dan R\&D.Bandung:Alfabeta.

Sanjaya, Wina. 2006.Pembelajaran dalam Implementasi Kurikulum Berbasis Kompetensi. Jakarta: Kencana Prenada Media Group. 